\title{
Predicting runoff and sediment connectivity and soil erosion by water for different land use scenarios in the Spanish Pre-Pyrenees
}

\author{
M. López-Vicente ${ }^{a, *}$, J. Poesen ${ }^{a}$, A. Navas ${ }^{b}$, L. Gaspar ${ }^{b}$ \\ ${ }^{a}$ Dept. of Earth and Environmental Science, K.U. Leuven, GEO-INSTITUTE, Celestijnenlaan 200 E, 3001, Heverlee, Belgium \\ ${ }^{b}$ Dept. of Soil and Water, Experimental Station of Aula Dei, CSIC, Postal Box 202, 50080, Zaragoza, Spain \\ *Corresponding author. Tel.: +32620313 601. Email addresses: mvicente@eead.csic.es; mlopezvicente@gmail.com (M. López- \\ Vicente)
}

\begin{tabular}{ll} 
Submitted & 5 November 2009 \\
Submitted in revised form & 29 October 2010 \\
Accepted & 6 January 2011 $\rightarrow$ DOI:10.1016/j.catena.2011.01.001 \\
Published online (Article in press) in Elsevier & 5 February 2011 \\
Published in Catena 102: 62-73 (Issue March 2013: Scales in Soil Erosion) & 27 December 2012 \\
\hline
\end{tabular}

\section{ABSTRACT}

Overland flow connectivity and runoff and sediment trap effectiveness are currently the cutting edge topics in soil erosion research. The effect of agricultural terraces, irrigation channels and trails on runoff and soil erosion modelling at catchment scale is still a remaining research question. In this study we run the index of connectivity of Borselli et al. (2008) and a modified version of the revised Morgan, Morgan and Finney (RMMF) model to predict the hydrological connectivity and the rates of soil erosion under four different scenarios of land uses and land abandonment. This goal is achieved by using geographic information systems (GIS) in the Estanque de Arriba catchment (74 ha; Spanish Pre-Pyrenees) where 83 soil samples were collected. The different maps of hydrological connectivity were used to create runoff and sediment trap effectiveness masks that were included in the assessment of the effective cumulative runoff. The results showed that the index of connectivity was very high in the irrigation channels and walls of the agricultural terraces for the past and current scenarios. The runoff and sediment connectivity of the catchment from the hillsides to the lake decreased with an increasing vegetation cover and a decreasing number of linear landscape elements. The connectivity decreased from the past to the current scenario and from the current to the future scenario with vegetation recovery in the abandoned fields. The vegetation factor appeared to be more important than the disappearance of the agricultural terraces and channels to explain the changes in the connectivity at catchment scale. Random changes in the $I C$ values appeared between the current and the future scenario without vegetation recovery in some parts of the catchment and were related to the mathematical procedure of the model that combines the upslope and downslope components at each pixel. This 
information is of special relevance in areas disturbed by humans and those with complex topography. The average erosion rates ranged between 1.5 and $3.7 \mathrm{Mg} \mathrm{ha}^{-1} \mathrm{yr}^{-}$

${ }^{1}$ for the different land use scenarios decreasing with the increase of the vegetation recovery in the abandoned fields. A significant percentage of the study area will suffer more erosion in the early stage of future land abandonment with an increasing volume of overland flow in the fields at the bottom of the catchment whereas soil erosion will decrease significantly after long-term land abandonment with vegetation recovery. Further research is proposed to better account the changes that happen in the soil and vegetation parameters at the early stages of land abandonment. The results of this study suggest that current active systems could be stabilized by trapping and retaining eroded sediment by increasing the vegetation cover and preserving the agricultural terraces.

Keywords: Index of connectivity; Sediment trap effectiveness; RMMF model; Land abandonment; Soil erosion; Spanish Pyrenees

\section{Introduction}

An increasing number of studies have been recently dealt with the role of hydrological connectivity processes within the catchment (Cammeraat, 2004; Beguería, 2005; Lexartza-Artza and Wainwright, 2009), the temporal storage of runoff and run-on (Sheridan et al., 2009) and sediments (López-Vicente and Navas, 2010a; Notebaert et al., 2009) as well as the effect of human infrastructures (Callow and Smettem, 2009; Meerkerk et al., 2009) in the accuracy of the predictions of the soil erosion models. Runoff and erosion processes are often non-linear and scale dependent, which increase the uncertainty of the model predictions. One of the reasons for scale dependency is the influence of sinks, i.e. areas of infiltration and sedimentation, which lower the hydrological connectivity and decrease the area-specific runoff and sediment yield (Lesschen et al., 2009).

The connectivity concept allows the investigating of the effect of heterogeneities on the global behaviour of a system that contains those heterogeneities and it is an essential factor to take into account when modelling heterogeneous systems (Antoine et al., 2009). In the context of surface hydrology, the study of connectivity varies from author to author because water flow is not easily observable at every location at the same time, especially at the catchment scale where contrasting soils and different runoff-generating processes (infiltration-excess and saturation-excess) take place (Buda et al., 2009). 
Moreover, one of the key factors affecting the physical linkage of water and, indirectly, the sediment in catchments is that the connectivity is the combination of both static and dynamic process responses (Bracken and Croke, 2007).

The presence, configuration and location of the hydrological controlling features can strongly affect the volume of the runoff and run-on as well as the amount of sediment transport during storms (Verstraeten et al., 2006). Moreover, hydrological patterns can be dramatically changed as a consequence of human alteration (Cabezas et al., 2009). Agricultural terraces form an important feature of sloping landscapes in the Mediterranean countries (Petanidou et al., 2008) and other environments around the world (Acabado, 2009) and have an important effect on the hydrological processes as they reduce the slope gradient and length. Furthermore, Gallart et al. (1994) found that terracing in the eastern Spanish Pyrenees promotes the premature formation of saturated areas and increasing saturation overland flow. Despite the purpose and benefits perceived by the people who built them, there has been a prolonged trend of abandonment and removal of terraces in the Mediterranean (Navas et al., 2008). In many cases the maintenance of terraces has ceased following land abandonment and in other cases terraces have been removed to facilitate the mechanization of cropping systems. Socio-economic changes occurred in Spain over the last 50 years and more recent changes induced by the agrarian policy of the European Union have led to land abandonment and land use changes. Such changes have produced hydrological and edaphic modifications which have had an effect on soil erosion (Navas et al., 1997). As a result, a larger part of the landscape becomes connected to the river by continuous pathways of concentrated overland flow and artificial channelling of overland flow (Gallart et al., 1994).

Irrigation ditches, small and spread settlements and non-asphalted trails are other hydrological features that commonly appear in the Mediterranean landscapes. In this context several overland flow and sediment connectivity functions have been developed to mathematically quantify and model the different hydrological connectivity processes under different land use scenarios and topographic conditions (e.g. Ferro and Minacapilli, 1995; Antoine et al., 2009; Barron et al., 2009).

The runoff and sediment trap effectiveness (TE) of the different hydrological controlling features is a measurement of their capability to retain the runoff and reduce the amount of sediments moving downwards from their upslope contributing area (Schäuble et al., 2008). TE is a function of the mean local residence time and the 
effectiveness of the vegetation to reduce runoff volume and velocity depends on the characteristics of the vegetation itself (width and slope of the vegetation strip, vegetation height, density, stiffness and species composition), of the inflow (runoff velocity, discharge, and volume), and of the rainfall (Verstraeten et al., 2006). A previous study in a small sub-catchment in the Spanish Pre-Pyrenees proved the usefulness of adding information on the sediment trapping effectiveness of terraces and geomorphic structures to improve the assessment of overland flow and the predictions of annual soil erosion (López-Vicente et al., 2009b).

This study seeks to assess the effect of agricultural terraces, irrigation channels, trails, sinks, scarps and land abandonment on the hydrological connectivity of a small catchment and its consequences on predicting rates of soil erosion under four different scenarios of land uses. We tackle this goal by running a complex index of hydrological connectivity and a semi-physically based model of soil erosion with geographic information systems (GIS) in a small mountain catchment of the Spanish Pre-Pyrenees. The results of this study will contribute to better understand the impact of natural features and anthropogenic infrastructures on the processes of cumulative overland flow and run-on as well as allow identifying spatial changes in the location of erosive and deposition-prone areas under different land use scenarios, including land abandonment.

\section{Materials and methods}

\subsection{Site description and definition of the different land use scenarios}

The Estanque de Arriba catchment (74 ha) is an endorheic system that is part of the Estaña catchment (246 ha) and is located in the Spanish Central Pre-Pyrenees (Fig. 1a). This catchment holds a small and permanent lake of fresh water (1.7 ha) that has been under regional protection since 1997 and is included in the European NATURA 2000 network as Site of Community Importance. Elevation ranges between 679 and $892 \mathrm{~m}$ a.s.1. with a mean slope steepness of 25\%. The study area developed on Mesozoic and Neogene materials composed of gypsiferous marls, dolomites, limestones, ophites, and sparse saline deposits. The main soil types are Calcisols, Leptosols and Haplic Regosols with small patches of Gleysols, Gypsisols and Vertisols (Machín et al., 2008). The texture is mainly silty loam and in some parts of the catchment is silty clay loam.

This area has a continental Mediterranean climate with two humid periods, one in spring and a second in autumn and a dry summer with rainfall events of high intensity from July to October. The average annual rainfall was $586 \mathrm{~mm}$ for the period 1997- 
2006 at the reconstructed Estaña weather station. The study area is located between the semiarid areas of the Ebro valley to the south and the humid areas of the Pyrenees to the north. Hence, the strong inter-annual oscillation is registered for the annual rainfall depth and rainfall intensity.

Four land use scenarios representative for Mediterranean agro-ecosystems have been considered in this study. Sixteen land uses are distinguished nowadays and natural and anthropogenic areas are heterogeneously distributed with frequent changes in land uses from divides to slope-bottom and with a wide range of extension from very small to large size polygons. Crops of winter barley is the main land use ( $24 \%$ of the total surface) as well as dense (17\%) and open (19\%) Mediterranean forest and dense (12\%) and sparse (10\%) scrublands. Abandoned fields are located on the steep slopes with many decaying cropping terraces (Fig. 2a). For the past conditions abandoned fields are considered as cultivated areas and fourteen land uses are distinguished, whereas all fields, pastures and orchards are considered as abandoned fields for the two future scenarios and thirteen land uses are considered. The extension and type of the different land uses for the past and current scenarios is supported by aerial photographs taken in 1960 and 2009, respectively. Two different future scenarios are simulated: the first one simulates a total vegetation recovery on the abandoned fields (simulating consequences at long-term) and is based on the study of Molinillo et al. (1997) on plant colonization and succession in abandoned fields of the Central Pyrenees. Whereas the second scenario is run considering no vegetation recovery and simulating short-term consequences after land abandonment or after forest fire or dry conditions in a nonfavorable scenario of climate change. Climate, topography, land uses and tillage practices in the Estaña catchment are representative of rainfed areas in countries of the Mediterranean basin.

\subsection{Estimation of the index of connectivity}

In this study we use the index of connectivity (IC) based on GIS data proposed by Borselli et al. (2008). This index takes into account the characteristics of the drainage area (upslope module) and the flow path length that a particle has to travel to arrive at the nearest sink (downslope module). In particular, this index provides an estimate of the potential connection between the sediment eroded from hillsides and the stream system. For each point or cell of the catchment, the $I C$ estimates the upslope and the downslope components, $D_{u p}$ and $D_{d n}$, respectively. The $D_{d n}$ factor considers the 
probability that sediment arrives at a sink along a flow line whereas the $D_{u p}$ factor summarizes the potential for downward routing of the sediment produced upslope and expands the same analysis to an area. The $I C$ is computed as follows:

$$
I C_{K}=\log _{10}\left(\frac{D_{u p, K}}{D_{d n, K}}\right)=\log _{10}\left(\frac{\overline{W_{K}} \cdot \overline{S_{K}} \cdot \sqrt{A_{K}}}{\sum_{i=K, n_{K}} \frac{d_{i}}{W_{i} \cdot S_{i}}}\right)
$$

where $\bar{W}$ is the average weighing factor of the upslope contributing area (dimensionless), $\bar{S}$ is the average slope gradient of the upslope contributing area $(\mathrm{m} / \mathrm{m})$, $A$ is the upslope contributing area $\left(\mathrm{m}^{2}\right), d_{i}$ is the length of the $i$ th cell along the downslope path (in m), $W_{i}$ is the weight of the $i$ th cell (dimensionless), and $S_{i}$ is the slope gradient of the $i$ th cell $(\mathrm{m} / \mathrm{m})$. Values of slope steepness lower than 0.005 must be replaced by the value $S_{i}=0.005$ to avoid computational mistakes or extreme values. The subscript $K$ indicates that each cell has its own $I C$-value. This index is defined in the range of $[-\infty,+\infty]$ and connectivity increases when $I C$ grows towards $+\infty$. Although the index of connectivity can change due to changes on rainfall intensity and tillage stages (drill, seed, grow, harvest, and soil with and without litter cover), in this study we compute an average annual value to allow comparing the different predicted values and derived maps of $I C$ for the different land use scenarios.

\subsection{The RMMF model of soil erosion}

The revised Morgan, Morgan and Finney $(R M M F)$ model (Morgan, 2001) is a semiphysically based model that estimates annual rates of soil detachment by splash $(F ; \mathrm{Mg}$ $\left.\mathrm{ha}^{-1} \mathrm{yr}^{-1}\right)$ and runoff $\left(H ; \mathrm{Mg} \mathrm{ha}^{-1} \mathrm{yr}^{-1}\right)$ and compares the total rate of detachment with the runoff transport capacity $\left(T C ; \mathrm{Mg} \mathrm{ha}^{-1} \mathrm{yr}^{-1}\right.$ ) to calculate the annual values of soil erosion $\left(E ; \mathrm{Mg} \mathrm{ha}^{-1} \mathrm{yr}^{-1}\right)$.

$$
E=\min \{(F+H), T C\}
$$

This model has been applied in many plots and catchments in several countries and under different climatic conditions and land use scenarios (e.g. Svorin, 2003; LópezVicente et al., 2008; Scholz et al., 2008; Ande et al., 2009). In this study the RMMF model is applied with the modifications proposed by López-Vicente and Navas (2010b) to consider the effect of the effective volume of the soil, the cumulative overland flow and the maximum surface storage capacity. 


\section{Soil particle detachment by raindrop impact}

The detachment of a soil particle by raindrop impact $\left(F ; \mathrm{Mg} \mathrm{ha}^{-1} \mathrm{yr}^{-1}\right)$ is computed from the total rainfall energy $\left(E ; \mathrm{J} \mathrm{m}^{-2}\right)$ and the parameter of soil erodibility $\left(K ; \mathrm{g} \mathrm{J}^{-1}\right)$.

$$
\begin{aligned}
& F=K \cdot E \cdot 10^{-2} \\
& E=E(D T)+E(L D)
\end{aligned}
$$

where $E(D T)\left(\mathrm{J} \mathrm{m}^{-2}\right)$ and $E(L D)\left(\mathrm{J} \mathrm{m}^{-2}\right)$ are the kinetic energy of the direct throughfall rainfall and the kinetic energy of the leaf drainage, respectively. The values of $K$ are obtained from Morgan (2001) for the different types of soil textures.

In this study, $E(D T)$ was determined using the equation of Coutinho and Tomás (1995) developed in southern Portugal and considered suitable for the western Mediterranean areas. This equation estimates the kinetic energy of the rain $\left(K E ; \mathrm{J} \mathrm{m}^{-2}\right.$ $\left.\mathrm{mm}^{-1}\right)$ as a function of the rainfall intensity $\left(I ; \mathrm{mm} \mathrm{h}^{-1}\right)$. The kinetic energy of the leaf drainage, $E(L D)$, is dependent upon the height of the plant canopy $(P H ; \mathrm{m})$.

$$
\begin{aligned}
& E(D T)=D T \cdot K E=D T \cdot 35.9[1-0.559 \exp (-0.034 I)] \\
& E(L D)=\left(15.8 P H^{0.5}\right)-5.87
\end{aligned}
$$

where $D T(\mathrm{~mm})$ is the direct throughfall volume of rainfall estimated from the total depth of effective rainfall (ER, mm). When Eq. (6) yields a negative value, $E(L D)$ is assumed to be zero.

Effective rainfall $(E R, \mathrm{~mm})$ is estimated after accounting the way total annual rainfall $(R ; \mathrm{mm})$ is partitioned during interception $(A ; 0-1)$. The effective rainfall is split into direct throughfall, $D T$, which directly reaches the soil surface and leaf drainage $(L D ; \mathrm{mm})$, that is intercepted by the plant canopy and reaches the ground by stemflow or dripping from leaves. The split is a direct function of the percentage canopy cover $(C C, \%)$.

$$
\begin{aligned}
& E R=R \cdot A \\
& L D=E R \cdot C C \\
& D T=E R-L D
\end{aligned}
$$

Estimation of the effective runoff

Without soil crusting neither soil repellency rainfall becomes overland flow after topsoil is saturated and strongly depends on the distribution of rainfall and soil properties. The $R M M F$ model computes the annual volume of runoff per raster cell $(Q$; $\mathrm{mm})$ assuming that runoff occurs when the mean rain per erosive rain day $\left(R_{0} ; \mathrm{mm}\right)$ exceeds the soil moisture storage capacity $\left(R_{c} ; \mathrm{mm}\right)$ : 


$$
\begin{aligned}
& Q=R \cdot \exp \left(\frac{-R_{C}}{R_{0}}\right) \\
& R_{C}=1000 \cdot M S \cdot B D \cdot V o l_{e f f} \cdot E H D \cdot\left(\frac{E T_{a}}{E T_{0}}\right)^{0.5}
\end{aligned}
$$

where $M S$ is the soil moisture content at field capacity $\left(\% \mathrm{w} \mathrm{w} \mathrm{w}^{-1}\right), B D$ is the bulk density of the soil $\left(\mathrm{Mg} \mathrm{m}^{-3}\right), E H D$ is the effective hydrological depth of the soil (m) and $E T_{a} / E T_{0}$ is the ratio between the actual and potential evapotranspiration. In this study, the effective volume of the soil, $V_{o l} l_{\text {eff }}$ (value between 0 and 1), has also been considered. The effective volume is related to the volume of the soil that actually retains water and is considered to be the same as that occupied by the soil fraction with a grain size of less than $2 \mathrm{~mm}$. The term $E H D$ indicates the depth of soil within which the moisture storage capacity controls the generation of the runoff as a function of the plant cover. Values of $E H D$ correspond to those included in the RMMF model (Morgan, 2001) for the different land-uses.

The effective runoff ( $\left.C Q_{\text {eff }}\right)$ is defined as the rainfall which is neither retained on the land surface nor infiltrated into the soil and becomes overland flow until it is drained in one of the catchment channels (Chow et al., 1988). Hence, $C Q_{\text {eff }}$ is computed from the potential cumulative overland flow $\left(C Q_{0} ; \mathrm{mm}\right)$, the saturated hydraulic conductivity of the different soil types $\left(K_{f s} ; \mathrm{mm}\right.$ day $\left.^{-1}\right)$, the maximum soil surface storage capacity $\left(S S_{\max } ; \mathrm{mm}\right)$ and slope steepness $(S$; radian).

$$
\begin{aligned}
& C Q_{e f f}=\left(C Q_{0}-K_{f s}-S S_{\max }\right) \sin S \\
& S S_{\max }=0.5 \cdot R G \cdot \frac{\sin ^{2}(S I G-S)}{\sin (S I G)} \cdot \frac{\cot (S I G+S)+\cot (S I G-S)}{2 \cos (S I G) \cos (S)}
\end{aligned}
$$

where $R G(\mathrm{~mm})$ is the surface roughness, and $S I G$ (radian) is the angle of the surface soil and surface furrow. In this study, the potential cumulative overland flow, $C Q_{0}$, was calculated by using the recently published extension AccumPlus 1.0 for ArcView 3.x created by Schäuble et al. (2008) (free available at http://www.terracs.com/produkte/software/accum-plus.html). Within this extension the runoff volume per raster cell, $Q$, is accumulated downward from divides with a simple flow algorithm (D8) and values of $C Q_{0}$ are modified by a trap effectiveness factor (TE, $\%)$. A mask of sediment trapping effectiveness was created for each land use scenario from the maps of the index of connectivity $(I C)$. The original values of $I C$ were scaled to fit between 0 (maximum hydrological and sediment connectivity) and 100 (total 
sedimentation or null connectivity) percent. According to Borselli et al. (2008) the highest negative values of $I C$ correspond to areas with intense sedimentation whereas positive values of $I C$ or values close to zero appear in areas of high connectivity without detectable sedimentation.

The maximum surface storage capacity was calculated according to Driessen (1986). A $S I G$ value of $30^{\circ}$ was considered valid for the study area based on Terzoudi et al. (2007). Surface roughness is the configuration of the soil caused by the randomly orientated arrangement of soil clods. Tillage tools can produce random roughness and orientated roughness. In this study the values of $R G$ proposed by Renard et al. (1997) are used for forest areas (random roughness, $R G=20.3 \mathrm{~mm}$ ) and for cultivated fields with plough $(R G=48.3 \mathrm{~mm})$ and field cultivator $(R G=17.8 \mathrm{~mm})$.

A correction was made to the different maps of the effective runoff for the ephemeral streams because erosion by overland flow stops as soon as the overland flow reaches the stream. To account this effect the estimated volume of runoff at the beginning of the gullies is considered as the maximum runoff volume.

Soil particle detachment by runoff

The $R M M F$ model estimates the detachment of soil by runoff $\left(H ; \mathrm{Mg} \mathrm{ha}^{-1} \mathrm{yr}^{-1}\right)$ as a function of the runoff volume, slope steepness ( $S$; radian) and the resistance of the soil $\left(Z ; \mathrm{kPa}^{-1}\right)$.

$$
\begin{aligned}
& H=Z \cdot C Q_{\text {eff }}^{1.5} \cdot \sin S \cdot(1-G C) \cdot 10^{-2} \\
& Z=\frac{1}{0.5 \cdot C O H}
\end{aligned}
$$

where $G C$ is the percentage of ground cover and includes crop residues and rocks and $\mathrm{COH}(\mathrm{kPa})$ is the cohesion of the soil. Values of cohesion were obtained from Morgan (2001) for the different textures of the soil. Equation (14) assumes that soil detachment by runoff only occurs where the soil is not protected by the ground cover.

\section{Runoff transport capacity}

The transport capacity of runoff $\left(T C ; \mathrm{Mg} \mathrm{ha}^{-1} \mathrm{yr}^{-1}\right)$ is computed from the effective runoff volume $\left(C Q_{e f f}\right)$, the slope steepness $(S)$, and the $C$ and $P$ factors of the RUSLE model (Renard et al., 1997).

$$
T C=C \cdot P \cdot C Q_{e f f}{ }^{2} \cdot \sin S \cdot 10^{-2}
$$

\subsection{Soil sampling and data collection}


Rainfall daily values from the reconstructed Estaña weather station (period 19972006; 10 years) are used to characterize the annual rainfall, whereas the rainfall data recorded at $15 \mathrm{~min}$ resolution at the Canelles weather station $(11 \mathrm{~km}$ southeast from the study area) for the same period are used to calculate the typical value of the rainfall intensity $\left(I=15.1 \mathrm{~mm} \mathrm{~h}^{-1}\right)$ and the mean annual rainfall per erosive rainday $\left(R_{0}=37.7\right.$ $\mathrm{mm})$. Annual values of the parameters of rainfall interception, canopy cover, plant height and the ratio between actual and potential evapotranspiration are those used by López-Vicente and Navas (2010a) for the different land covers at the Estaña catchment.

A total of 83 soil samples were collected (Fig 1b). Samples were air-dried, grinded, homogenized and quartered to pass through a $2 \mathrm{~mm}$ sieve and the weight percentage of coarse fragments was calculated. Laser equipment was used to determine the textural class of each sample. Values of bulk density and soil moisture content at field capacity were measured using metallic cylinders and porous ceramic plates in a closed chamber, respectively, and soil detachability and soil cohesion were estimated. The maps of the corresponding properties were created with the assistance of the Spline interpolator method that fits a minimum-curvature surface through the input points and the interpolated maps were used to run the RMMF model.

The values of $G C$ in Eq. (14) were obtained from the percentage of coarse fragments and the percentage of soil surface covered by crop residues was also considered in barley fields. The slope steepness and length and potential cumulative overland flow were calculated using an accurate digital elevation model (DEM) of the study area at a spatial resolution of $5 \times 5$ meters. The values of the $C$ and $P$ factors are those calculated by López-Vicente and Navas (2009) for the study area for the current land use scenario. New maps of the C-RUSLE factor were calculated according to the original equation of the RUSLE model (Renard et al., 1997) for the past and future scenarios.

From the different maps of land uses and the geomorphologic map (López-Vicente et al., 2009a) three different maps of the main hydrological features were created and used in this study for the simulation of the index of connectivity (Fig. 2b). Moreover, different maps for some parameters of this index and the $R M M F$ model were created to simulate the different conditions of the land covers for the different land use scenarios. Non-variable and time dependant input values are summarized in Table 1. All maps, the interpolation and the mathematical operations were done with the ArcView GIS 3.2 ${ }^{\circledR}$ and ArcGIS $9.0^{\circledR}$ applications at catchment scale with a spatial resolution of 5 x 5 meters of cell size. 


\section{Results and discussion}

\subsection{Hydrological connectivity}

Before the calculation of the index of connectivity a threshold value for the rivermask was estimated from the average value of the cumulative cells at the beginning of the permanent gullies. This value was equal to 372 cells and is lower than the value of 1000 cells used by default by Borselli et al. (2008) in the original article of the $I C$ model. This difference is explained by the small size of our study area. The average index of connectivity for the Estanque de Arriba catchment was $-4.8,-5.0,-5.4$ and 5.2 for the past, current, future1 (land abandonment and vegetation recovery) and future2 (land abandonment and no vegetation recovery) scenarios, respectively (Fig. 3), showing an overall trend of decreasing hydrological connectivity with the decrease in the number of hydrological controlling features in the study area. These average values indicate that the runoff and sediment connectivity was higher in the past and sedimentation-prone conditions become more frequent for the current and the two future scenarios with partly and total ruined agricultural terraces and channels, respectively. These results apparently disagree with the results of Meerkerk et al. (2009) in abandoned landscapes in south-eastern Spain where the decrease in intact terraces led to a strong increase in connectivity and runoff discharge.

To tackle with these conflicting results a spatial analysis of the variation in the $I C$ values between the different scenarios was done and different patterns of spatial changes were observed (Fig. 4). The values of $I C$ were high in the two irrigation channels for the past and current scenarios, especially in the channel located at the bottom of the hillside in the northern part of the catchment. This channel was built in the area where slope steepness strongly changes and the channel collects most of the runoff volume and sediments from the contributing upslope. Collected overland flow and sediments are directly transferred to the lake. Hence, this infrastructure is one of the main features controlling connectivity in the study area and the good agreement between the model predictions and the field observations makes the application of the IC model under different scenarios feasible. The lack of irrigation channels in the future 1 and future 2 scenarios was reflected by the lower values of $I C$ in this area and the maps show how the runoff and sediments are spread from the hillside to the gentle slopes surrounding the lake. 
From the past to the current scenario Equation (1) predicts a clear decrease in the index of connectivity for the abandoned fields (increase of sedimentation) that is mathematically explained by the changes of the input values of the model related to vegetation parameters (factor $W=C$-RUSLE). At the same time an increase in the hydrological connectivity is predicted in the trails and in the main overland flow paths of the catchment, especially in the lower areas of the catchment that surround the lake. These results agree with the field measurements of runoff reported by Cerdà (1997) in old abandoned fields with vegetation recover in south-eastern Spain and confirm that the recovery of vegetation is particularly efficient in reducing water delivery to the main flow paths of the catchment. Molina et al. (2009) also found runoff transmission losses due to the recovery of vegetation from the experimental field data in the Ecuadorian Andes with land abandonment. Morellón et al. (2010) found a good correlation between the maximum lake levels of the Estaña catchment and the maximum expansion of agriculture and the decline in the lake levels with a decrease in human pressure (land abandonment and vegetation recovery) in a multi-proxy study with robust chronological control. These results obtained for long-term land-use changes (latest 1000 years) agree and support the results obtained in this study for short and medium-term changes in land uses.

From the current to the future 2 scenario changes of the $I C$ values indicate a slight change to a more sedimentation-prone situation. This result highlights the key role of the vegetation cover ( $W$ factor) controlling the different values of the $I C$ obtained in the future 1 and future 2 scenarios, as the river-mask layer was the same in the two future scenarios. Moreover, no spatial pattern was identified in the changes of $I C$ between the current and the future 2 scenarios. The lack of irrigation channels and terraces in the two future scenarios lead to a simplified map of connectivity where topographic factors (slope and cumulative cells) and vegetation parameters ( $W$ factor) explain the spatial distribution of the $I C$ values. We suggest that further research with the $I C$ model may pay more attention to the changes in the soil and vegetation parameters at the first stages of land abandonment to improve the assessment of the $W$ factor. Moreover, some authors have seen that the relationship of the vegetation cover to soil erosion is highly complex and for semiarid conditions in prevailing Mediterranean environments soil does not generally lead to a stabilisation in the geomorphodynamic process activity until vegetation cover increase up to $>60 \%$ (Sauer and Ries, 2008). 
Random changes in the connectivity of the catchment appeared in the trails and downward from several anthropogenic and natural features. The spatial analysis of the changes of the hydrological connectivity suggests that the response of the Estanque de Arriba catchment to land use changes not only depends on the overall land use change, but also on the spatial distribution of the vegetation patches and infrastructures, and also as a consequence of the mathematical procedure of the model that combines the upslope and downslope components at each cell. These results agree with the conclusions of Vanacker et al. (2005) after assessing the impact of land abandonment and land use changes on the hydrological and sediment connectivity at the catchment scale. Lesschen et al. (2009) also found that the spatial distribution of vegetation and terraces largely determined hydrological connectivity at the catchment scale. Hence, distributed hydrological and erosion models should take into account relevant natural sinks and infrastructures in order to correctly simulate the runoff and erosion-sedimentation patterns. These results are also of interest for the assessment of the potential effect of decreasing vegetation cover in mountainous Mediterranean areas due to frequent forest fire (Cerdà and Lasanta, 2005) and climate change on soil erosion and runoff and sediment transport.

\subsection{Overland flow and soil erosion}

The maps of the effective cumulative runoff, $C Q_{e f f}$, showed a complex spatial pattern where processes of overland flow in gullies, topographic thresholds (gentle and steep slopes), high infiltration rates and human infrastructures (terraces and channels) influence the predicted values (Fig. 5). Most of the excess-saturation runoff from the upslope directly reached the irrigation channels in the past and current scenarios and was derived to the lake through this infrastructure showing a quite realistic pattern. These results prove the usefulness of combining the $I C$ and the modified $R M M F$ models to improve the predictions of the cumulative runoff within catchments with human disturbances. High values of the cumulative runoff were also predicted at the walls of the terraces whereas much lower values of $C Q_{\text {eff }}$ appeared in the area of the fields located between the terraces. These anthropogenic structures are characterized by high values of trapping effectiveness and create areas of temporal accumulation of the overland flow.

Irrigation channels and terraces were removed for the future 1 and future 2 scenarios and their maps of $C Q_{\text {eff }}$ showed the typical pattern of the cumulative overland flow. No 
significance variation appeared between the spatial patterns of $C Q_{\text {eff }}$ for the two future scenarios and only small changes in their values were predicted. In the four scenarios areas with very low values of $C Q_{\text {eff }}$ either zero appeared in the soil types with very high rates of saturated hydrological conductivity.

The average rate of soil erosion, $\bar{E}$, was $3.7,2.5,1.5$ and $2.3 \mathrm{Mg} \mathrm{ha}^{-1} \mathrm{yr}^{-1}$ for the past, current, future1 and future 2 scenarios, respectively. The decrease in the soil erosion rates mainly reflects the recovery of the vegetation in the abandoned fields, and in a minor way responds to the decrease in the index of connectivity (increase of the trapping effectiveness) (Fig. 6). Although $\bar{E}_{\text {future2 }}$ is lower than $\bar{E}_{\text {current }}$ higher values of soil erosion were predicted in $20 \%$ of the surface of the study area for the future 2 scenario, whereas only $10 \%$ of the surface presented lower rates of soil loss. Those areas with higher rates in the future 2 scenarios are mainly located in the new simulated abandoned fields and underline an increase of soil erosion at the first stage of the land abandonment. The lack of irrigation channels caused an increase in the cumulative overland flow that reached these fields and promoted an increase in the soil erosion rates. For the future 1 scenario and simulating soil erosion with vegetation recovery $7 \%$ of the total surface had higher values of soil erosion than in the current scenario, and $30 \%$ of the surface presented lower rates. These results agree with the higher rates of soil erosion observed in the field by Cerdà (1997) in 3-year-abandoned fields (similar to the future2 scenario) in south-eastern Spain than the measured rates in the cultivated fields and the very low values of the runoff and erosion observed in the 10-yearabandoned fields (similar to the future1 scenario) with a well-developed vegetation cover. García-Ruiz et al. (1995) also observed a decrease in the runoff and sediment yield due to the replacement of cereals by meadows, and the expansion of bushes in the former cultivated fields in the Central Pyrenees under similar conditions of this study.

The maps of the spatial variation of the values of soil erosion between the different land use scenarios mirror the maps of the changes of the index of connectivity appearing with higher values of soil loss in those areas where the hydrological connectivity increases (Fig. 7). Conversely, where the values of $I C$ decrease (indicating a change to a sediment-prone condition) soil erosion rates decrease. The good agreement between the RMMF and the IC models gives confidence to the methodology proposed in this study.

The highest rates of erosion were obtained in the gully system (higher than $30 \mathrm{Mg}$ $\left.\mathrm{ha}^{-1} \mathrm{yr}^{-1}\right)$, trails $\left(>4 \mathrm{Mg} \mathrm{ha}^{-1} \mathrm{yr}^{-1}\right)$, crops $\left(>3 \mathrm{Mg} \mathrm{ha}^{-1} \mathrm{yr}^{-1}\right)$, open Mediterranean forest (around $2 \mathrm{Mg} \mathrm{ha}^{-1} \mathrm{yr}^{-1}$ ) and disperse scrublands (around $1.5 \mathrm{Mg} \mathrm{ha}^{-1} \mathrm{yr}^{-1}$ ) for the four 
land use scenarios (Table 2). Recent abandoned fields for the current scenario and orchards in the past scenario also presented high values of soil erosion. Almost no erosion was predicted in pastures, oak forest, dense Mediterranean forest and dense scrublands (lower than $0.1 \mathrm{Mg} \mathrm{ha}^{-1} \mathrm{yr}^{-1}$ ). The values of soil erosion decreased progressively from the past to the current scenario, from the current to the future 2 and from the future 2 to the future 1 scenarios, according to the increase of the vegetation cover. High values of soil erosion are predicted in those pixels located at the walls of the terraces (high values of cumulative runoff) whereas the fields located between the walls showed lower rates.

The validation of the predictions of soil erosion was done with the available rates of net soil loss and deposition quantified with ${ }^{137} \mathrm{Cs}$ in the fields that surround the lake (see López-Vicente and Navas, 2009 for more detail). These fields are close to the outlet of the catchment where the effects of the changes in the runoff connectivity and cumulative overland flow are summarized. The mean value of the quantified soil loss was $2.1 \mathrm{Mg} \mathrm{ha}^{-1} \mathrm{yr}^{-1}$ in the control points, whereas the mean estimated rate was 4.7, 4.7, 0.3 and $2.6 \mathrm{Mg} \mathrm{ha}^{-1} \mathrm{yr}^{-1}$ for the past, current, future1 and future2 scenarios, respectively. The similar values of predicted soil erosion for the past and current scenarios in the control points are explained because these points are located in the cultivated fields that have not suffered any change between the past and current conditions. The erosion rates for cropland in the gentle sloping areas and on steep slopes, quantified with ${ }^{137} \mathrm{Cs}$, averaged 4.2 and $49.1 \mathrm{Mg} \mathrm{ha}^{-1} \mathrm{yr}^{-1}$, respectively, in other fields of the Estaña catchment (López-Vicente and Navas, 2010b) showing very similar values to those predicted for the current scenario of land uses (see Fig. 6). These results suggest that the modified $R M M F$ model coupled with the $I C$ model slightly overestimated the rates of soil erosion though both predicted and quantified rates were in the same grade of magnitude and validation of the results can be considered good. Nonetheless, the scale dependence of the processes of the runoff production, soil erosion and sediment delivery (Buck et al., 2004; López-Vicente and Navas, 2010a) suggest that the application of the selected procedure in this study may be checked in the larger catchments to assess its feasibility in other study sites.

Climate change predictions over the Mediterranean basin for the next decades include an increase of the temperature (between 2 and $4^{\circ} \mathrm{C}$, under the A2 and B2 emission scenarios) and a widespread drop in the summer rainfall that is partially compensated by a winter precipitation increase (Giannakopoulos et al., 2009). This 
climatic scenario coupled with the results of this study for the two future scenarios of land uses and the current high erodibility of most of the Mediterranean soils will give rise to more fragile agro-ecosystems in which soil will essentially constitute a nonrenewable resource. Hence, the quick recovery of the vegetation in the abandoned and projected set-aside lands may be considered by the policy-makers of the regional, national and European Union institutions and included in their agendas.

\section{Conclusions}

The index of connectivity was calculated in the Estanque de Arriba catchment allowing the spatial identification of the depositional- and hydrological connected-prone areas. The IC model successfully represented the intense hydrological connectivity processes that take place in the irrigation channels and in the walls of the agricultural terraces. The lack of these infrastructures in the future scenarios leads to a typical pattern of the cumulative overland flow where only the topographic and land cover parameters explain the spatial variation and values. The overall runoff and sediment connectivity of the catchment from the hillslopes to the lake showed a decreasing rate with an increasing vegetation cover and a decreasing number of anthropogenic structures from the past to the current scenario and from the current to the future scenario with vegetation recovery in the abandoned fields. Random changes in the connectivity of the catchment appeared in the same areas as a consequence of the mathematical procedure of the model with the GIS techniques underlying the complexity of its assessment. The vegetation factor appeared to be as important as the disappearance of the agricultural terraces and channels to explain the changes in the connectivity at the catchment scale. However, the $I C$ model does not take into account the changes in the soil and vegetation parameters at the early stages of land abandonment and further research is proposed on these topics.

The use of the trap effectiveness maps derived from the index of connectivity has allowed successfully the modelling of the processes of effective cumulative runoff in the areas of the irrigation channels and the walls of the terraces. These results provide insights to improve the knowledge on the dynamic of runoff generation and suggest that the application of the trap effectiveness mask layers is of interest to improve the predictions of the distributed runoff and soil erosion models. This information is of special relevance in areas disturbed by humans and those with complex topography such as most of the productive agro-ecosystems in all the countries. 
The average erosion rates range between 1.5 and $3.7 \mathrm{Mg} \mathrm{ha}^{-1} \mathrm{yr}^{-1}$ for the different land use scenarios decreasing with the increase of the vegetation recovery in the abandoned fields. A significant percentage of the study area will suffer more erosion in the early stage of land abandonment whereas soil erosion will decrease significantly after long-term land abandonment with vegetation recovery. These results suggest a reinforcement of the erosion processes at the beginning of land abandonment and support and conservation practices are recommended in these high erosive-prone areas. Moreover, current active systems could be stabilized by trapping and retaining eroded sediment by increasing the vegetation cover and preserving the agricultural terraces.

\section{Acknowledgements}

This research was financially supported by the project: "Soil erosion and carbon dynamic in Mediterranean agroecosystems: radioisotopic modelling at different spatial and temporal scales (MEDEROCAR, CGL2008-00831/BTE)" funded by the Spanish Ministry of Science and Innovation. This study was also conducted with cooperation from the EC-DG RTD- $6^{\text {th }}$ Framework Research Programme (sub-priority 1.1.6.3)-Research on Desertification- project DESIRE (037046): Desertification Mitigation and Remediation of land - a global approach for local solutions. M. López-Vicente would also like to acknowledge the Alfonso Martín Escudero Foundation for its postdoctoral fellowship for the year 2010 and to Mrs. Elena Calvo-Seas for her collaboration in the field surveys.

\section{References}

Acabado, S., 2009. A Bayesian approach to dating agricultural terraces: a case from the Philippines. Antiquity 83 (321), 801-814.

Ande, O.T., Alaga, Y., Oluwatosin, G.A., 2009. Soil erosion prediction using MMF model on highly dissected hilly terrain of Ekiti environs in southwestern Nigeria. International Journal of Physical Sciences 4 (2), 53-57.

Antoine, M., Javaux, M., Bielders, C., 2009. What indicators can capture runoff-relevant connectivity properties of the micro-topography at the plot scale? Advances in Water Resources 32 (8), 1297-1310.

Barron, O.V., Pollock, D.W., Dawes, W.R., 2009. Evaluation of catchment connectivity and storm runoff in flat terrain subject to urbanisation. Hydrology and Earth System Sciences Discussions 6, 6721-6758.

Beguería, S., 2005. Erosión y fuentes de sedimento en la cuenca del embalse de Yesa (Pirineo Occidental): Ensayo de una metodología basada en teledetección y análisis SIG. Instituto Pirenaico de Ecología, 158 pp., Zaragoza, Spain.

Borselli, L., Cassi, P., Torri, D., 2008. Prolegomena to sediment and flow connectivity in the landscape: A GIS and field numerical assessment. Catena 75 (3), 268-277.

Bracken, L.J., Croke, J., 2007. The concept of hydrological connectivity and its contribution to understanding runoffdominated geomorphic systems. Hydrological Processes 21 (13), 1749-1763.

Buck, O., Niyogi, D.K., Townsend, C.R., 2004. Scale-dependence of land use effects on water quality of streams in agricultural catchments. Environmental Pollution 130 (2), 287-299. 
Buda, A.R., Kleinman, P.J.A., Srinivasan, M.S., Bryant, R.B., Feyereisen, G.W., 2009. Factors influencing surface runoff generation from two agricultural hillslopes in central Pennsylvania. Hydrological Processes 23 (9), 12951312.

Cabezas, A., Comin, F.A., Begueria, S., Trabucchi, M., 2009. Hydrologic and landscape changes in the Middle Ebro River (NE Spain): implications for restoration and management. Hydrology and Earth System Sciences 13 (2), 273-284.

Callow, J.N., Smettem, K.R.J., 2009. The effect of farm dams and constructed banks on hydrologic connectivity and runoff estimation in agricultural landscapes. Environmental Modelling \& Software 24 (8), 959-968.

Cammeraat, E.L.H., 2004. Scale dependent thresholds in hydrological and erosion response of a semi-arid catchment in southeast Spain. Agriculture, Ecosystems \& Environment 104 (2), 317-332.

Cerdà, A., 1997. Soil erosion after land abandonment in a semiarid environment of southeastern Spain. Arid Soil Research and Rehabilitation 11 (2), 163-176.

Cerdà, A., Lasanta, T., 2005. Long-term erosional responses after fire in the Central Spanish Pyrenees: 1. Water and sediment yield. Catena 60 (1), 59-80.

Chow, V.T., Maidment, D.R., Mays, L.W., 1988. Applied Hydrology. McGraw-Hill: New York, NY; 572.

Coutinho, M.A., Tomás, P.P., 1995. Characterization of raindrop size distributions at the Vale Formoso Experimental Erosion Center. Catena 25 (1-4), 187-197.

Driessen, P.M., 1986. The water balance of soil. In: van Keulen, H., Wolf, J. (Eds.), Modeling of Agricultural Production: Weather, Soils and Crops. Pudoc: Wageningen, The Netherlands; 76-116.

Ferro, V., Minacapilli, M., 1995. Sediment delivery processes at basin scale. Hydrological Sciences Journal - Journal des Sciences Hydrologiques 40 (6), 703-717.

Gallart, F., Llorens, P., Latron, J., 1994. Studying the role of old agricultural terraces on runoff generation in a small Mediterranean mountainous basin. Journal of Hydrology 159 (1-4), 291-303.

García-Ruiz, J.M., Lasanta, T., Ortigosa, L., Ruiz-Flaño, P., Martí, C., González, C., 1995. Sediment Yield under Different Land Uses in the Spanish Pyrenees. Mountain Research and Development 15 (3), 229-240.

Giannakopoulos, C., Le Sager, P., Bindi, M., Moriondo, M., Kostopoulou, E., Goodess, C.M., 2009. Climatic changes and associated impacts in the Mediterranean resulting from a $2^{\circ} \mathrm{C}$ global warming. Global and Planetary Change 68 (3), 209-224.

Lesschen, J.P., Schoorl, J.M., Cammeraat, L.H., 2009. Modelling runoff and erosion for a semi-arid catchment using a multi-scale approach based on hydrological connectivity. Geomorphology 109 (3-4), 174-183.

Lexartza-Artza, I., Wainwright, J., 2009. Hydrological connectivity: Linking concepts with practical implications. Catena 79 (2), 146-152.

López-Vicente, M., Navas, A., 2009. Predicting soil erosion with RUSLE in Mediterranean agricultural systems at catchment scale. Soil Science 174 (5), 272-282.

López-Vicente, M., Navas, A., 2010a. Distributed modelling of soil erosion and sediment yield in a karstic catchment of the Spanish Pre-Pyrenees. Environmental Earth Sciences 61 (1), 143-158.

López-Vicente, M., Navas, A., 2010b. Routing runoff and soil particles in a distributed model with GIS: implications for soil protection in mountain agricultural landscapes. Land Degradation and Development 21 (2), 100-109.

López-Vicente, M., Navas, A., Machín, J., 2008. Modelling soil detachment rates in rainfed agrosystems in the southcentral Pyrenees. Agricultural Water Management 95 (9), 1079-1089.

López-Vicente, M., Navas, A., Machín, J., 2009a. Geomorphic mapping in endorheic catchments in the Spanish Pyrenees: An integrated GIS analysis of karstic features. Geomorphology 111 (1-2), 38-47.

López-Vicente, M., Navas, A., Machín, J., Gaspar, L., 2009b. Effect of terraces, sinks and scarps in modelling cumulative overland flow and soil erosion at catchment scale. Geophysical Research Abstracts 11, EGU20091493-1. 
Machín, J., López-Vicente, M., Navas, A., 2008. Cartografía digital de suelos de la Cuenca de Estaña (Prepirineo Central). In: Benavente, J., Gracia, F.J. (Eds.), Trabajos de Geomorfología en España, 2006-2008. SEG, Cádiz, Spain. pp. 481-484.

Meerkerk, A.L., van Wesemael, B., Bellin, N., 2009. Application of connectivity theory to model the impact of terrace failure on runoff in semi-arid catchments. Hydrological Processes 23 (19), 2792-2803.

Molina, A., Govers, G., Van den Putte, A., Poesen, J., Vanacker, V., 2009. Assessing the reduction of the hydrological connectivity of gully systems through vegetation restoration: field experiments and numerical modelling. Hydrology and Earth System Sciences 13 (10), 1823-1836.

Molinillo, M., Lasanta, T., García-Ruiz, J.M., 1997. Managing mountainous degraded landscapes after farmland abandonment in the Central Spanish Pyrenees. Environmental Management 21 (4), 587-598.

Morellón, M., Valero-Garcés, B., González-Sampériz, P., Vegas-Vilarrúbia, T., Rubio, E., Rieradevall, M., DelgadoHuertas, A., Mata, P., Romero, O., Engstrom, D.R., López-Vicente, M., Navas, A., Soto, J., 2010. Climate changes and human activities recorded in the sediments of Lake Estanya (NE Spain) during the Medieval Warm Period and Little Ice Age. Journal of Paleolimnology. doi:10.1007/s10933-009-9346-3.

Morgan, R.P.C., 2001. A simple approach to soil loss prediction: a revised Morgan-Morgan-Finney model. Catena 44 (4), 305-322.

Navas, A., García-Ruiz, J.M., Machín, J., Lasanta, T., Valero, B., Walling, D.E., Quine, T.A., 1997. Soil erosion on dry farming land in two changing environments of the central Ebro Valley, Spain. In: Human impact on erosion and sedimentation. Book Series: IAHS Publication 245, 13-20.

Navas, A., Machín, J., Beguería, S., López-Vicente, M., Gaspar, L., 2008. Soil properties and physiographic factors controlling the natural vegetation re-growth in a disturbed catchment of the Central Spanish Pyrenees. Agroforestry Systems 72 (3), 173-185.

Notebaert, B., Verstraeten, G., Rommens, T., Vanmontfort, B., Govers, G., Poesen, J., 2009. Establishing a Holocene sediment budget for the river Dijle. Catena 77 (2), 150-163.

Petanidou, T., Kizos, T., Soulakellis, N., 2008. Socioeconomic dimensions of changes in the agricultural landscape of the Mediterranean basin: A case study of the abandonment of cultivation terraces on Nisyros Island, Greece. Environmental Management 41 (2), 250-266.

Renard, K.G., Foster, G.R., Weesies, G.A., McCool, D.K., Yoder, D.C., 1997. Predicting Soil Erosion by Water: A Guide to Conservation Planning With the Revised Universal Soil Loss Equation (RUSLE). Handbook \#703. US Department of Agriculture: Washington, DC.

Sauer, T., Ries, J.B., 2008. Vegetation cover and geomorphodynamics on abandoned fields in the Central Ebro Basin (Spain). Geomorphology 102 (2), 267-277.

Schäuble, H., Marinoni, O., Hinderer, M., 2008. A GIS-based method to calculate flow accumulation by considering dams and their specific operation time. Computers \& Geosciences 34, 635-646.

Scholz, G., Quinton, J.N., Strauss, P., 2008. Soil erosion from sugar beet in Central Europe in response to climate change induced seasonal precipitation variations. Catena 72 (1), 91-105.

Sheridan, G.J., Jones, O.D., Lane, P.N.J., 2009. Stochastic rainfall-runoff equations for quantifying runoff and pollutant connectivity between hillslopes and streams. Geophysical Research Abstracts 11, EGU2009-3845.

Svorin, J., 2003. A test of three soil erosion models incorporated into a geographical information system. Hydrological Processes 17 (5), 967-977.

Terzoudi, C.B., Gemtos, T.A., Danalatos, N.G., Argyrokastritis, I., 2007. Applicability of an empirical runoff estimation method in central Greece. Soil and Tillage Research 92 (1-2), 198-212.

Vanacker, V., Molina, A., Govers, G., Poesen, J., Dercon, G., Deckers, S., 2005. River channel response to shortterm human-induced change in landscape connectivity in Andean ecosystems. Geomorphology 72 (1-4), 340353. 
Verstraeten, G., Poesen, J., Gillijns, K., Govers, G., 2006. The use of riparian vegetated filter strips to reduce river sediment loads: an overestimated control measure? Hydrological Processes 20 (20), 4259-4267. 


\section{Table 1}

Permanent and time variable input values in the RMMF model and index of connectivity.

\begin{tabular}{|c|c|c|c|}
\hline Variable & Description & \multicolumn{2}{|c|}{$\begin{array}{c}\text { Different maps for the different } \\
\text { land-use scenarios }\end{array}$} \\
\hline \multicolumn{4}{|c|}{ Index of connectivity (IC) } \\
\hline S & Slope steepness & No & \\
\hline “Mask" & Map of the hydrological controlling features & & Yes \\
\hline DEM & Digital elevation model & No & \\
\hline $\mathrm{C}$ & C-RUSLE factor & & Yes \\
\hline \multicolumn{4}{|c|}{ RMMF model } \\
\hline I & Rainfall intensity & No & \\
\hline $\mathrm{R}$ & Total annual rainfall & No & \\
\hline $\mathrm{R}_{0}$ & Mean rainfall per erosive rainday & No & \\
\hline A & Rainfall interception & & Yes \\
\hline $\mathrm{CC}$ & Canopy cover & & Yes \\
\hline $\mathrm{PH}$ & Plant height & & Yes \\
\hline MS & Soil moisture content at field capacity & No & \\
\hline BD & Bulk density & No & \\
\hline EHD & Effective hydrological depth & & Yes \\
\hline $\mathrm{Vol}_{\mathrm{eff}}$ & Effective volume & No & \\
\hline $\mathrm{ET}_{\mathrm{a}}$ & Actual evapotranspiration & No & \\
\hline $\mathrm{ET}_{0}$ & Potential evapotranspiration & No & \\
\hline $\mathrm{K}_{\mathrm{fs}}$ & Saturated hydraulic conductivity & No & \\
\hline $\mathrm{SS}_{\max }$ & Maximum soil surface storage capacity & & Yes \\
\hline S & Slope steepness & No & \\
\hline GC & Ground cover & & Yes \\
\hline $\mathrm{COH}$ & Cohesion of the soil & No & \\
\hline RG & Soil roughness & & Yes \\
\hline $\mathrm{C}$ & C-RUSLE factor & & Yes \\
\hline$P$ & P-RUSLE factor & & Yes \\
\hline
\end{tabular}




\section{Table 2}

Statistic values of annual soil loss for the different land covers at the Estanque de Arriba catchment (NE Spain) under different scenarios of land uses: Past (year 1960); Current (year 2009); Future1: land abandonment and vegetation recovery; Future2: land abandonment and no vegetation recovery.

\begin{tabular}{|c|c|c|c|c|c|c|c|c|}
\hline \multirow{3}{*}{$\begin{array}{l}\text { Land use and } \\
\text { land cover type }\end{array}$} & \multicolumn{8}{|c|}{ Annual soil loss $\left(\mathrm{Mg} \mathrm{ha}^{-1} \mathrm{yr}^{-1}\right)$} \\
\hline & \multicolumn{2}{|c|}{ Past } & \multicolumn{2}{|c|}{ Current } & \multicolumn{2}{|c|}{ Future1 } & \multicolumn{2}{|c|}{ Future2 } \\
\hline & Mean & SD & Mean & SD & Mean & SD & Mean & SD \\
\hline \multicolumn{9}{|c|}{ Anthropogenic Use } \\
\hline Recent abandoned field & - & - & 6.4 & 14.7 & 0.5 & 2.3 & 2.9 & 10.5 \\
\hline Trail & 4.8 & 12.8 & 6.1 & 15.2 & 4.2 & 12.3 & 4.5 & 12.8 \\
\hline Cereal crop & 6.2 & 22.0 & 3.2 & 12.0 & - & - & - & - \\
\hline Orchard & 2.7 & 8.2 & 0.7 & 2.1 & - & - & - & - \\
\hline Old abandoned field & - & - & 0.1 & 0.4 & $<0.1$ & 0.2 & 1.1 & 6.5 \\
\hline Pasture & $<0.1$ & 0.1 & $<0.1$ & 0.1 & - & - & - & - \\
\hline \multicolumn{9}{|c|}{ Natural vegetation } \\
\hline Gully (bare soil) & 42.4 & 58.4 & 36.8 & 53.5 & 31.6 & 47.3 & 32.7 & 48.5 \\
\hline Open Medit. forest & 2.6 & 10.0 & 2.4 & 8.3 & 1.8 & 4.9 & 2.0 & 5.7 \\
\hline Disperse scrubland & 1.8 & 7.3 & 1.4 & 5.8 & 1.2 & 4.5 & 1.3 & 4.7 \\
\hline Poplar & 0.2 & 0.5 & 0.2 & 0.4 & 0.2 & 0.6 & 0.2 & 0.6 \\
\hline Bank vegetation & 0.1 & 0.6 & 0.1 & 0.6 & 0.1 & 0.6 & 0.1 & 0.6 \\
\hline Dense Medit. forest & $<0.1$ & 0.6 & $<0.1$ & 0.1 & $<0.1$ & 0.1 & $<0.1$ & 0.1 \\
\hline Dense scrubland & $<0.1$ & 0.1 & $<0.1$ & 0.1 & $<0.1$ & 0.2 & $<0.1$ & 0.2 \\
\hline Oak forest & $<0.1$ & $<0.1$ & $<0.1$ & $<0.1$ & $<0.1$ & $<0.1$ & $<0.1$ & $<0.1$ \\
\hline
\end{tabular}


Fig. 1. a) Geographic situation of the Estanque de arriba catchment within the Ebro river basin (NE Spain) and b) aerial orthophoto of the study site with location of the sampling points.

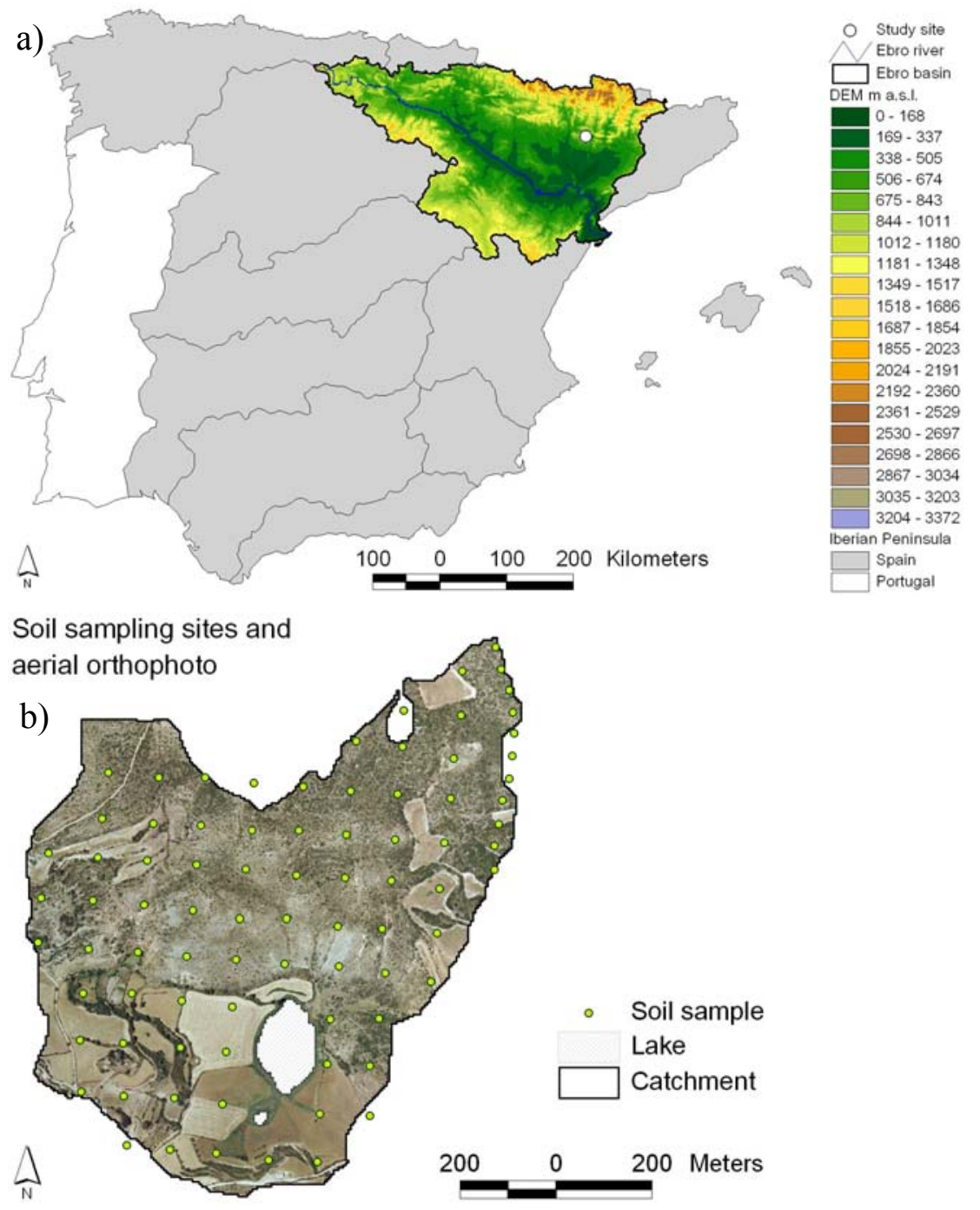


1 Fig. 2. a) Map of land uses of the study area and b) of the hydrological controlling features for the past, current and future scenarios.
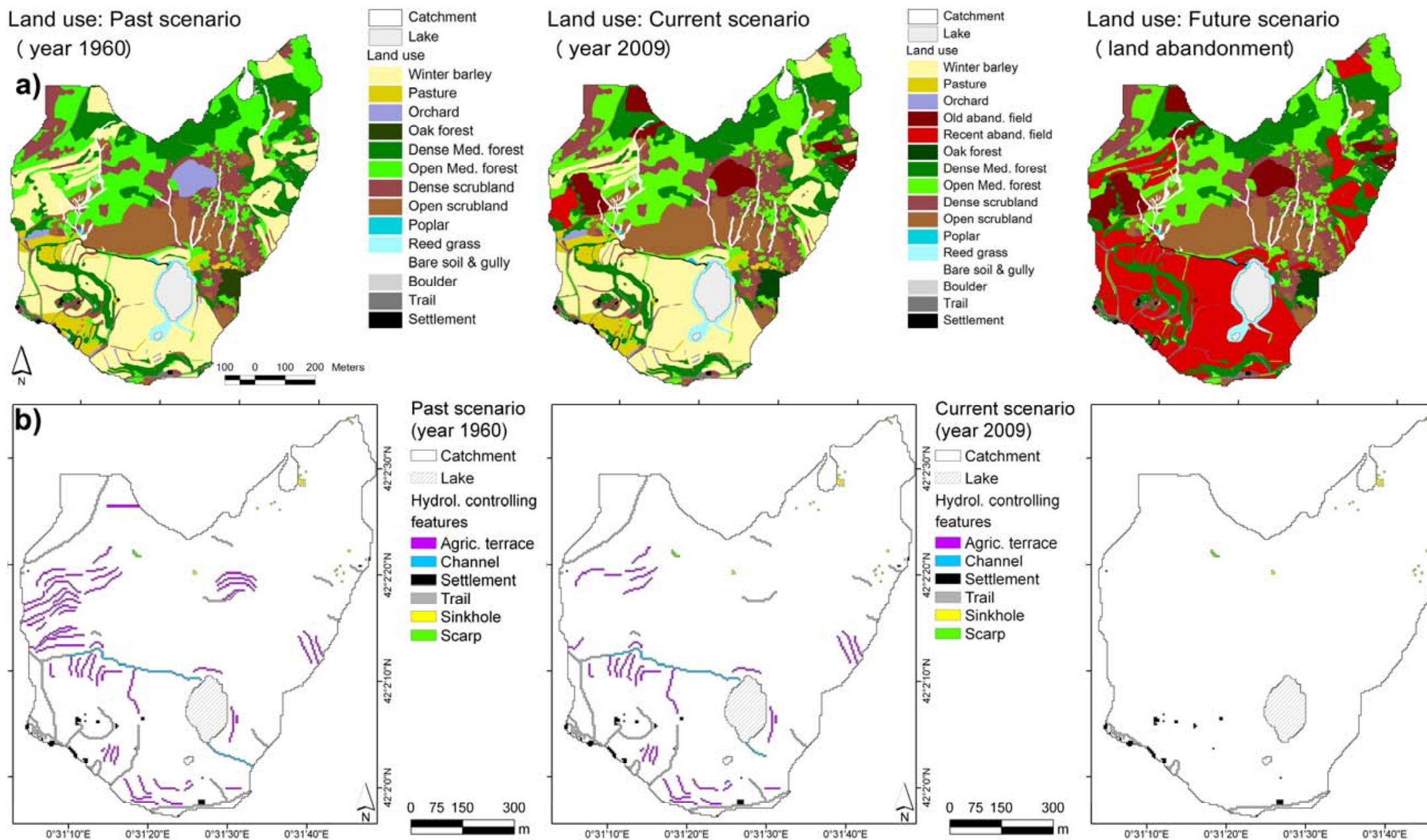

$\square$ Catchment Lake and use

\section{b)}

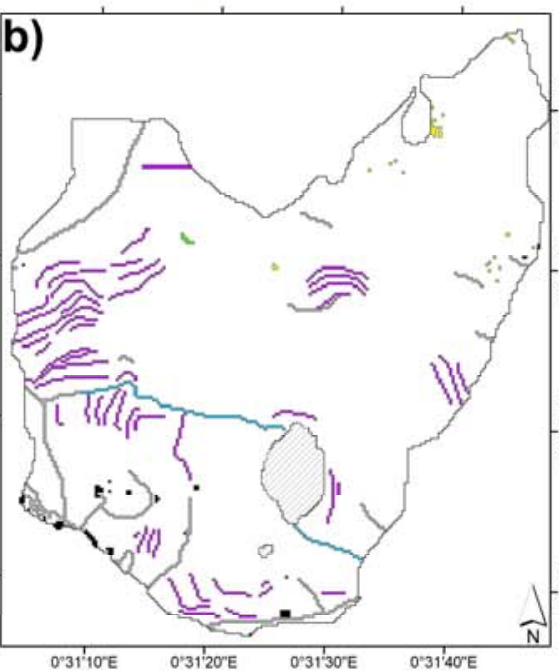

Past scenario (year 1960)
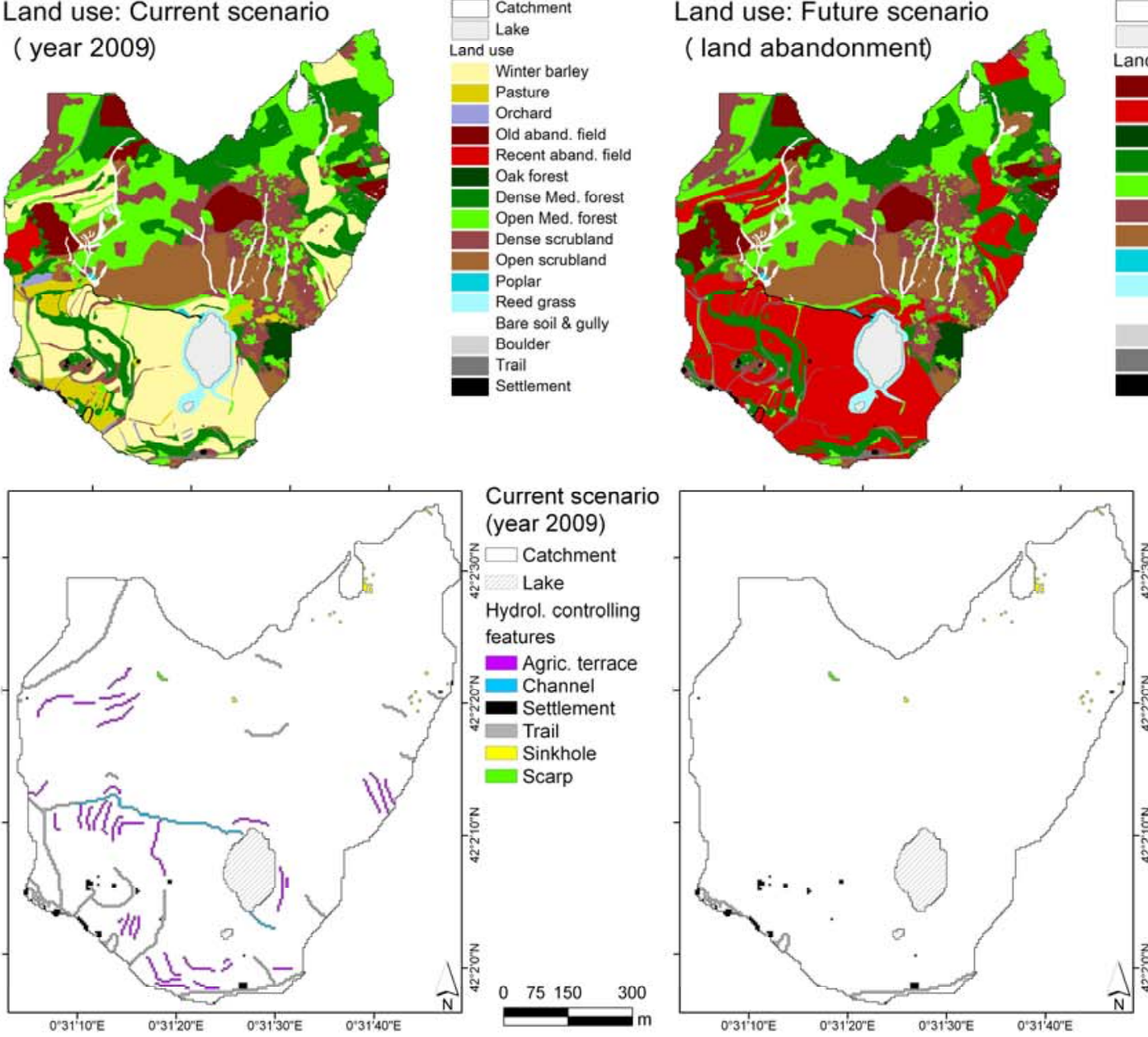

Future scenario (total land abandonment)

Lake Hydrol. controlling features

- Agric. terrace

Channel

- Trail

Sinkhole
Scarp

$\frac{-2}{3}$

0.3110E 0.3120 E 0.3130E 0.3140" E

$0031^{1} 10$ $\square$ Catchment Lake Hydrol. controlling features - Settlemen Trail Sinkhole
Scarp

Old aband. field Oak forest

Dense Med. fores

Open Med. forest

Dense scrubland

Poplar

Reed grass

Boulder

Settlement

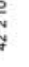


4 Fig. 3. Map of the index of connectivity for the past, current and two different future scenarios.
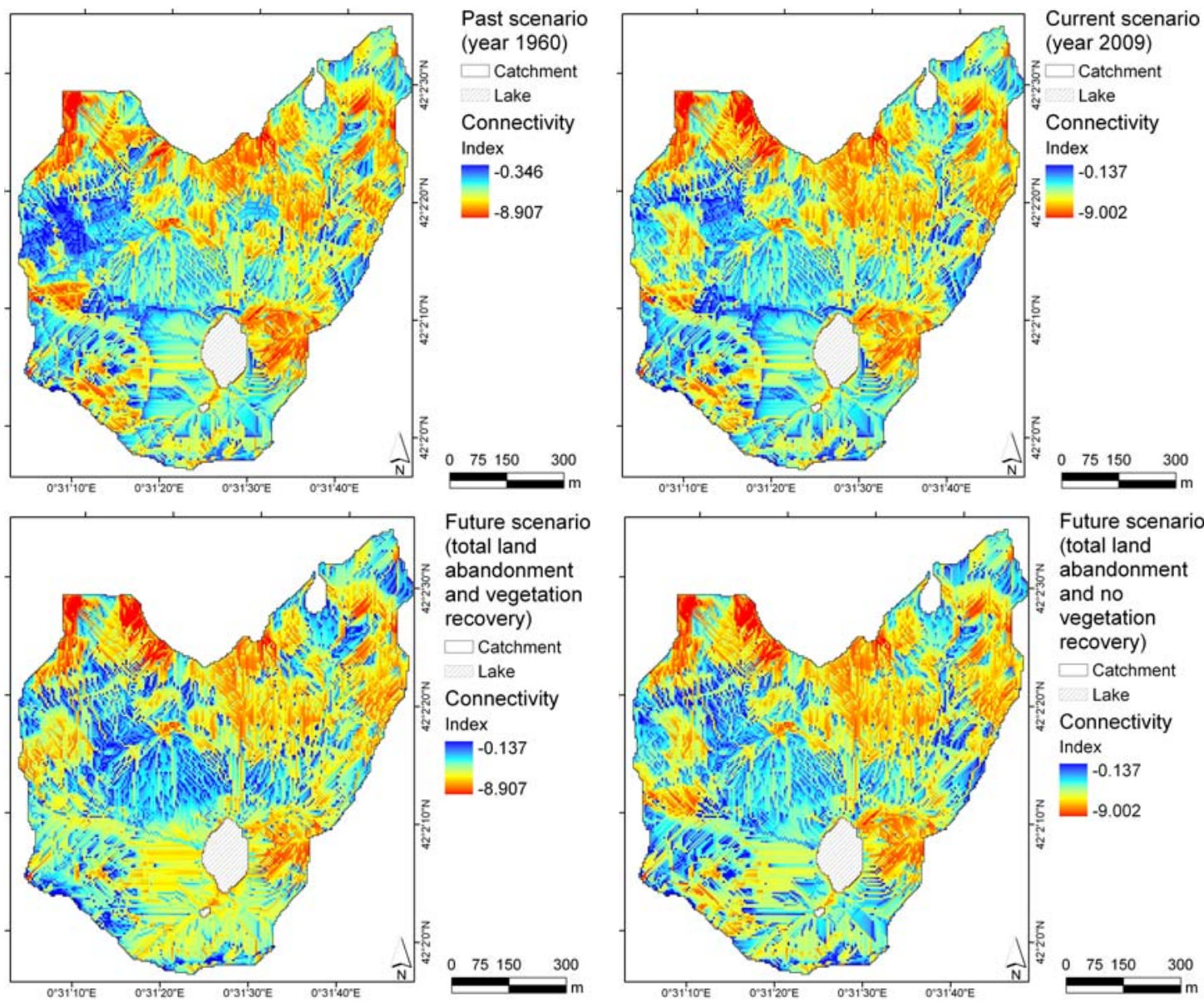
8 Fig. 4. Map of changes in the index of connectivity, $I C$, between the current and past scenarios, the 9 future1 (land abandonment and vegetation recovery) and current scenarios and between the future 2 (land 10 abandonment and no vegetation recovery) and current scenarios.

Sediment connectivity: Current vs. Past

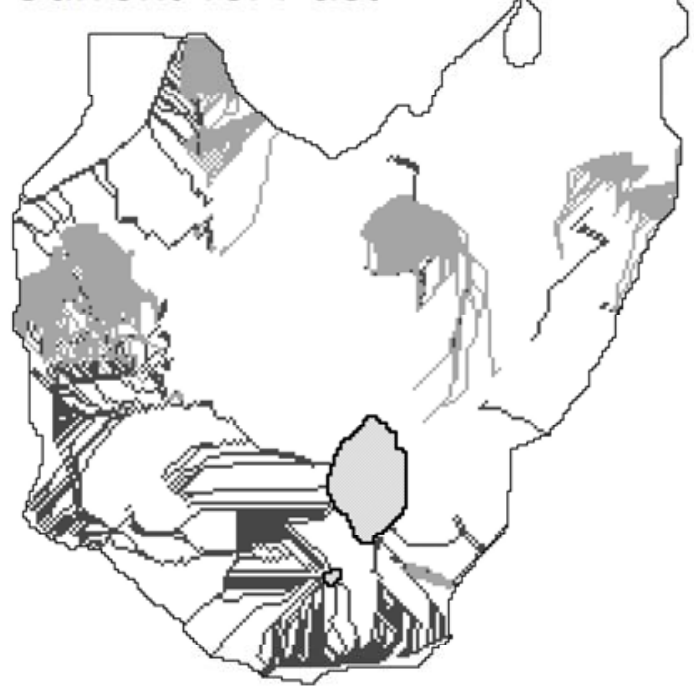

Sediment connectivity: 11 Future2 vs. Current

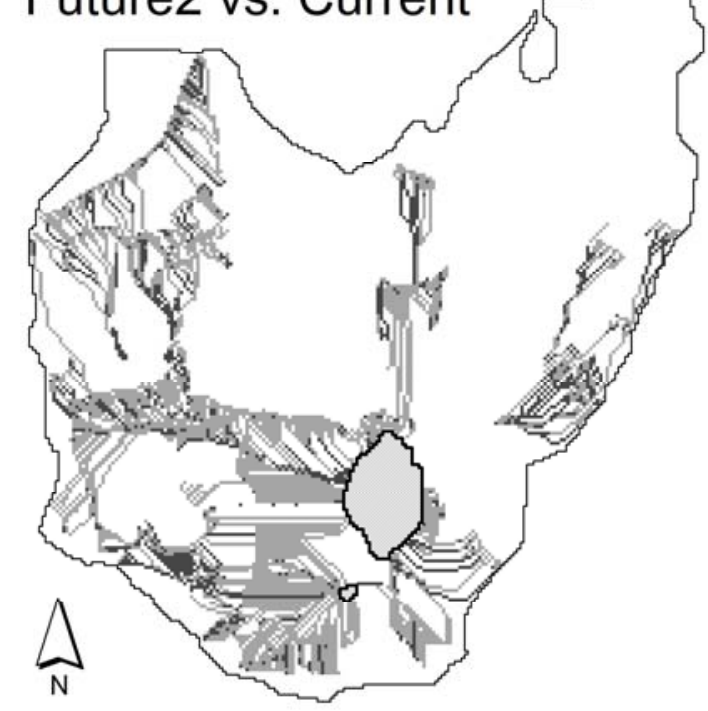

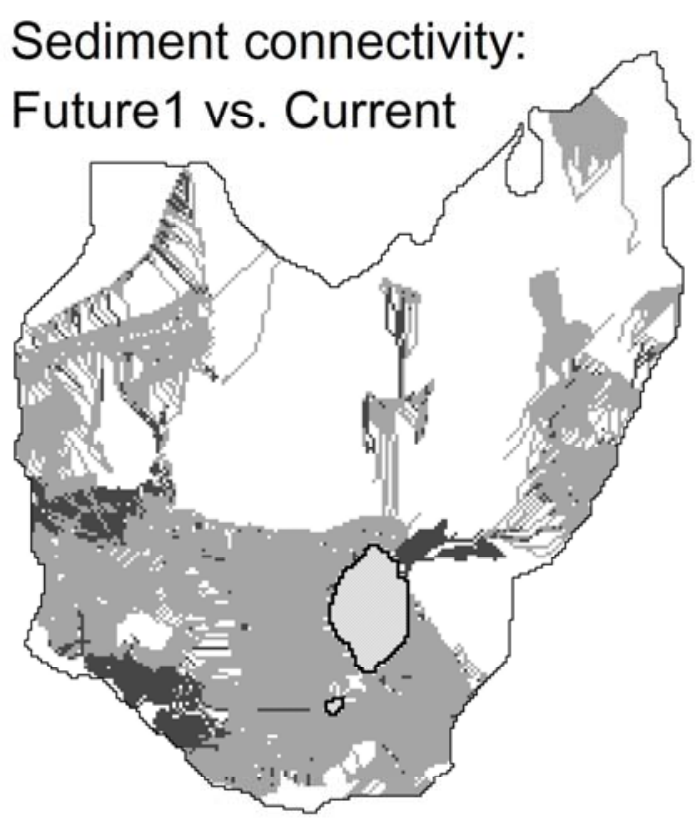

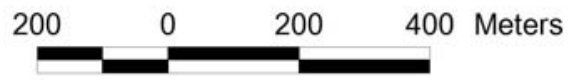


14 Fig. 5. Maps of effective cumulative runoff for the different scenarios of land uses.
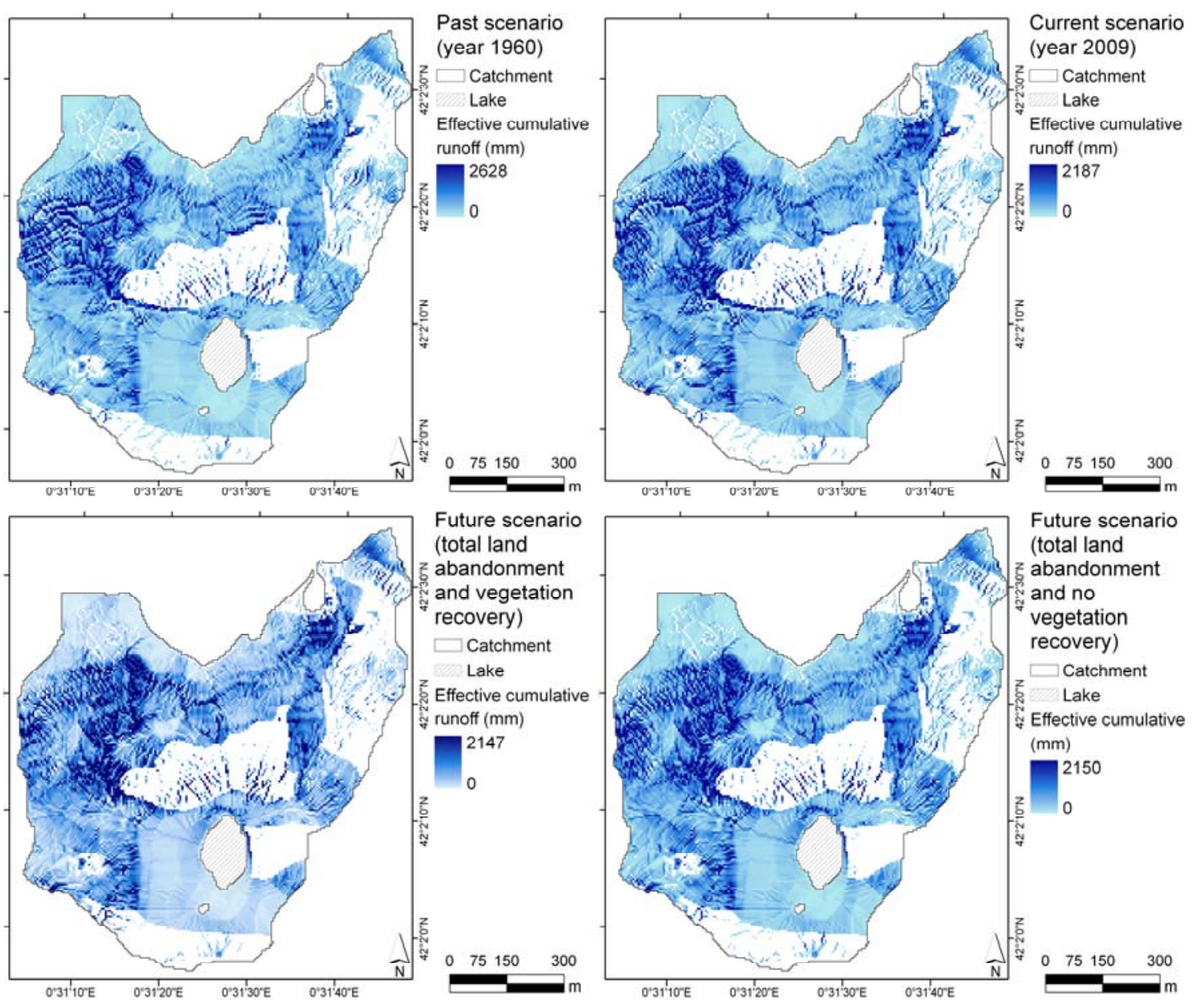
18 Fig. 6. Maps of soil erosion at the Estanque de Arriba catchment (NE Spain) for the past (year 1960), 19 current (year 2009), future1 (land abandonment and vegetation recovery) and future2 (land abandonment 20 and no vegetation recovery) scenarios of land uses.
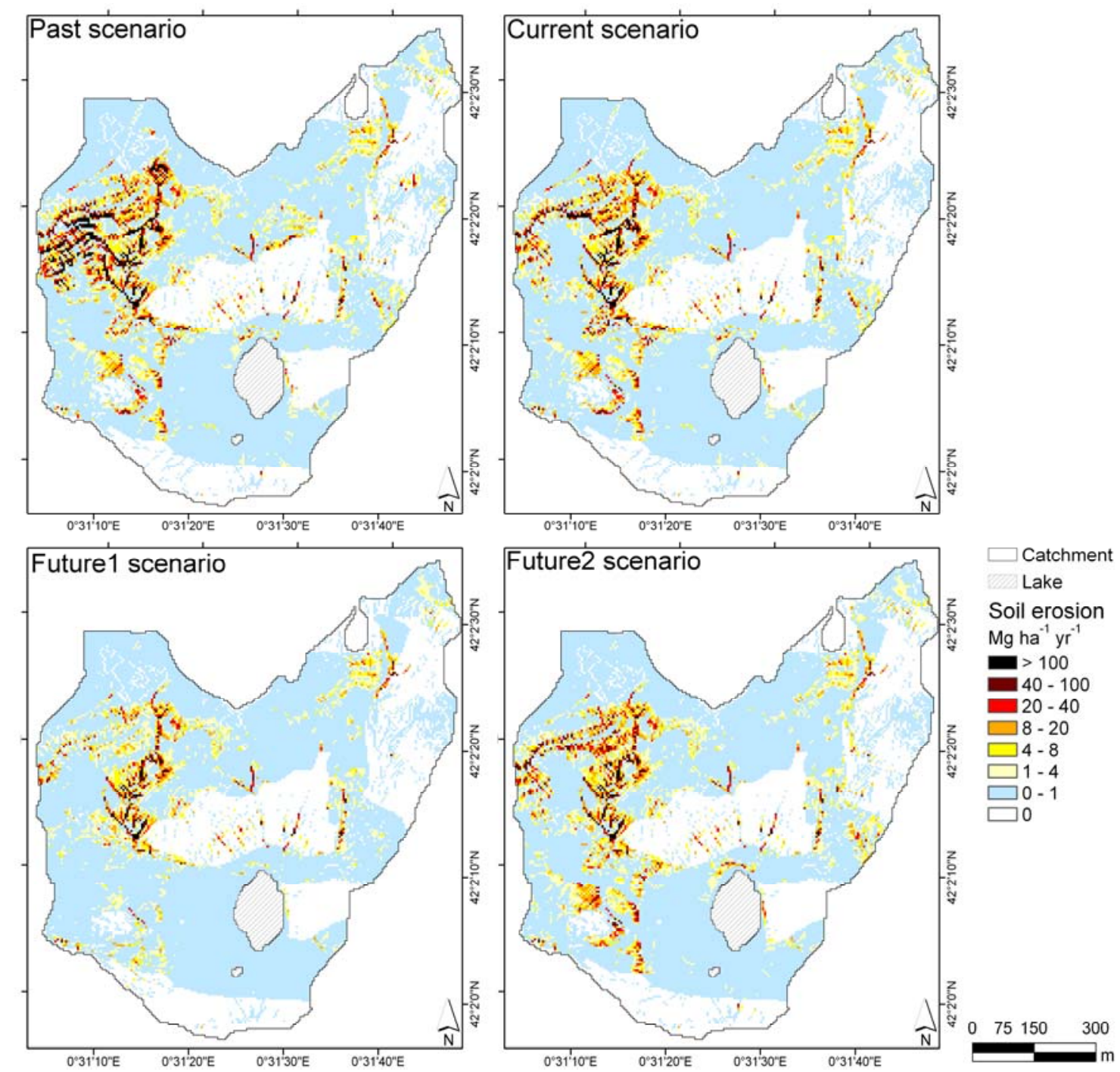
Fig. 7. Maps of changes in the values of predicted soil erosion between the current and past scenarios, the future1 (land abandonment and vegetation recovery) and current scenarios and between the future2 (land abandonment and no vegetation recovery) and current scenarios.

\section{Soil erosion:}

Current vs. Past

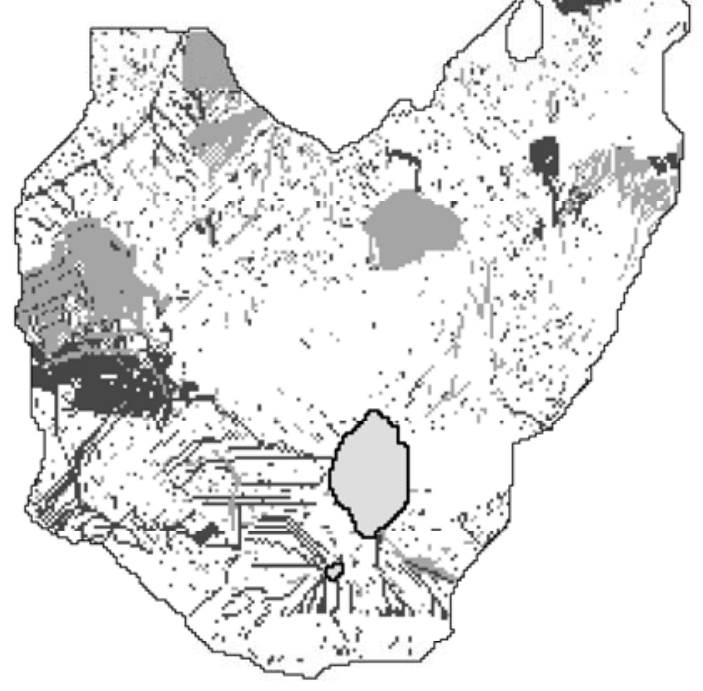

\section{Soil erosion:}

\section{Future2 vs. Current}

27

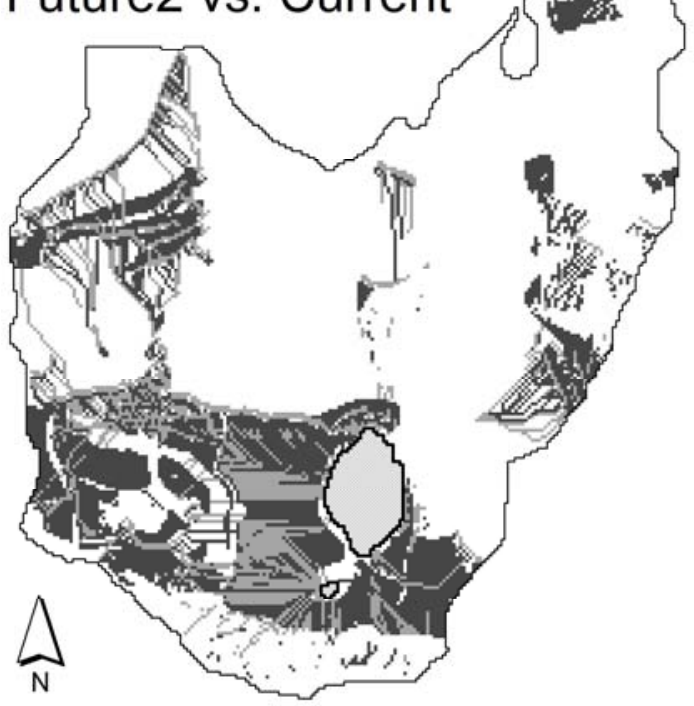

Soil erosion:

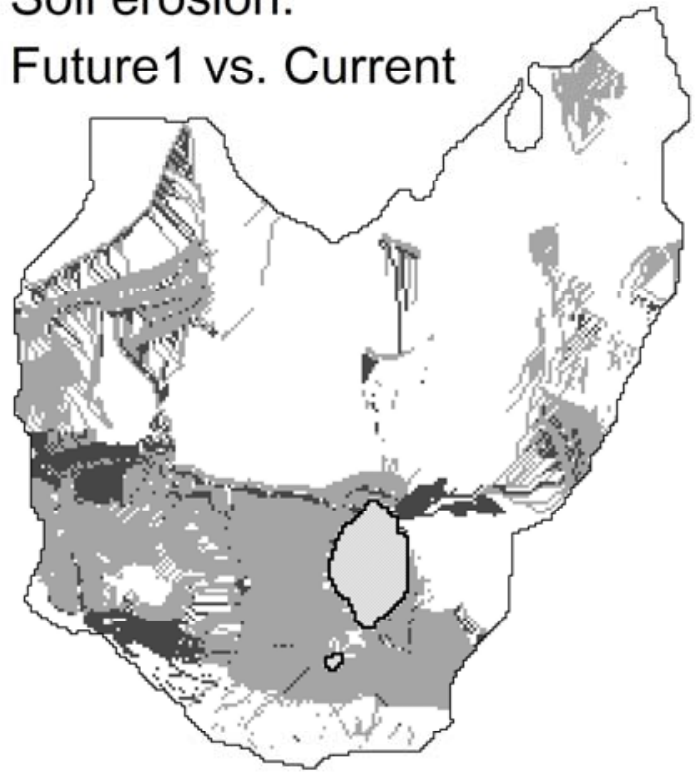

